\title{
LIBERALES DE 1812 Y RELACIONES IGLESIA-ESTADO
}

\author{
M.T. REGUEIRO GARCÍA
}


SUMARIO

1. INTRODUCCIÓN; 2. PROYECTO DE CONCILIO. MEDIDAS FISCALES Y LIBERTAD DE IMPRENTA; 2.1 Medidas fiscales; 2.2 Libertad de imprenta; 3. RELACIONES IGLESIA-ESTADO EN LA CONSTITUCIÓN DE 1812; 4. LOS LIBERALES Y LA SUPRESIÓN DE LA INQUISICIÓN; 5. ACTUACIONES DE LOS LIBERALES EN LA REFORMA DE LAS ORDENES RELIGIOSAS Y DESAMORTIZACIÓN; 6. LOS LIBERALES Y EL PROBLEMA DE LAS DISPENSAS. EL NOMBRAMIENTO DE OBISPOS; 7. LOS LIBERALES Y OTROS ASPECTOS DE LAS RELACIONES IGLESIA-ESTADO; 8. INFLUENCIA DE LAS IDEAS LIBERALES EN LAS RELACIONES IGLESIA-ESTADO. 


\title{
LIBERALES DE 1812 Y RELACIONES IGLESIA-ESTADO
}

\author{
POR \\ M.T. REGUEIRO GARCÍA \\ Profesora Titular Derecho Eclesiástico del Estado \\ UNED
}

\section{INTRODUCCIÓN}

En este artículo vamos a examinar las ideas y actuaciones de los liberales españoles sobre las relaciones Iglesia-Estado durante el periodo 1808-1813, periodo en el que se elaboró la Constitución de 1812, se desarrolló la Guerra de la Independencia y se confeccionó una abundante legislación tendente a modificar la estructura del Antiguo Régimen.

Para los liberales doceañistas, las relaciones Iglesia-Estado, y en general todo lo relacionado con la religión, tuvieron una importancia relevante, ya que deseaban sustituir el caduco edificio del Antiguo Régimen, del cual la primera era uno de sus pilares, por un nuevo sistema constitucional. No se trataba de alterar los dogmas ni de atacar la religión, sino de variar la organización de la Iglesia, pero prescindiendo del permiso papal. Las modificaciones en las relaciones citadas se pueden examinar desde dos aspectos diferentes: uno, estructural, como el deseo de sustituir a la Iglesia del Antiguo Régimen por una nueva acorde con sus ideas, otro como el conjunto coyuntural de medidas para satisfacer necesidades económicas o calmar polémicas ideológicas surgidas entre los propios liberales. En el primero de los aspectos, se trató de que se acomodase la Iglesia a los ideales liberales de: (i) libertad, para lo que resultaba ne- 
cesaria la supresión de la Inquisición (ii) predominio de la propiedad individual, para lo que era imprescindible la eliminación de las vinculaciones de la tierra, e (iii) igualdad, que conllevaba a la eliminación de jurisdicciones y privilegios fiscales; todo ello conducía para los miembros de la Iglesia española, según los liberales, a una dependencia orgánica de los obispos en lo referente a los temas espirituales y de la autoridad temporal en lo tocante a los aspectos socio-económicos. Como puede observarse, la gran renovación política propugnada por los liberales no podía llevarse a cabo sin modificar el estatus vigente hasta ese momento de las relaciones Iglesia-Estado y en este punto coincidieron con muchos de los postulados de la tendencia jansenista, que sería su aliada en la mayoría de los debates de las Cortes. Lo que en ningún caso fue posible era eliminar la Iglesia, con la que gran parte del pueblo español se sentía plenamente identificado y aun más en una situación como la que se dio en la Guerra de la Independencia, en al que tomó parte muy activa. La solución adoptada por los liberales doceañistas fue la de tratar de integrar a la Iglesia en su sistema, pero una Iglesia reformada y acomodada a las nuevas ideas, al nuevo Estado y a la nueva sociedad. Puede decirse que las reformas no fueron una consecuencia de actitudes antirreligiosas, sino consecuencia de la puesta en práctica del ideario liberal.

Ante esta necesidad de renovar la Iglesia del Antiguo Régimen el primer liberalismo español, aliado con el jansenismo, presentó un modelo nuevo basado en el episcopalismo regalista, la reforma moral del clero, la simplificación de la devoción popular y la lucha contra el fanatismo y la superstición. En su opinión, los representantes de la nación soberana estaban legalmente capacitados para tomar cuantas medidas se estimasen necesarias para reformar la disciplina exterior de la Iglesia. De este modo, no solo se trataba de reducir el poder jurisdiccional de la Iglesia y reformar su estructura interna, sino que el programa reformistaregalista, en el marco liberal doceañista, persiguió hacer del catolicismo una verdadera «religión nacional» o religión civil y de sus ministros, agentes políticos de estabilización y propagación del nuevo ideario. Para lograrlo era preciso cambiar prácticas religiosas e instituciones eclesiales. Esta labor se pretendió abordar desde el poder legislativo en virtud de un regalismo asumido por entero y desde la propia Iglesia con la convocatoria de un concilio nacional, al tiempo que se exigía la renovación del episcopado. Este primer periodo liberal inició en consecuencia unas reformas religiosas relativamente escasas y moderadas, pero emotivamente muy relevantes, ya que sentaban el precedente de una política religiosa en la que el Estado liberal se sentía competente para alterar unilateralmente las relaciones Iglesia-Estado mediante modificaciones en las instituciones de la primera. 


\section{PROYECTO DE CONCILIO. MEDIDAS FISCALES Y LIBERTAD DE IMPRENTA}

La participación del clero en las Cortes de Cádiz fue muy relevante, ya que constituían el grupo más numeroso, oscilando, según diferentes fechas, entre los 90 y los 97 diputados, y en general formaban parte del denominado clero medio y alto: canónigos, dignidades y obispos. Destacaron en este grupo Muñoz Torrero, Espiga, Mejía, Villanueva y Oliveros por los liberales y jansenistas, así como Ostolaza e Inguanzo por los reaccionarios; es decir formaron parte de todos los grupos que se constituyeron. La participación del alto clero estaba en línea con la representación de otros grupos, de modo que se ha podido hablar de una asamblea de clases instruidas ${ }^{1}$. Además de esta participación directa, las Cortes impusieron el juramento de obediencia a las mismas por parte de los prelados y cabildos eclesiásticos, quienes debían exigirlo a sus subalternos. Hay que hacer notar esta notable participación pues desaparecería en las restantes Cortes del siglo XIX, excepto en el Trienio Liberal, condicionando así la aportación de la Iglesia a la España liberal.

La renovación de la Iglesia, que, según los liberales y jansenistas, debían emprender las nuevas Cortes, se podía realizar por diferentes vías, pero tanto la concordataria como la intervención directa del Papa quedaban descartadas en aquel momento por la situación personal de este último, prisionero e incomunicado por los franceses, con lo que quedaban abiertas tanto la vía de dependencia del Nuncio como la regalista y la conciliar. Además estas dos últimas vías contaban con el apoyo de los defensores del episcopalismo, entendido éste como la defensa de los derechos de los obispos frente a la Santa Sede, e incluso de algunos reaccionarios, ya que pensaban que era un modo de sustraer el tema de la influencia de las Cortes. De este modo, cuajó, al comienzo de la legislatura, la idea de celebrar un Concilio Nacional, por lo que se presentó una propuesta a las Cortes el 22 de agosto de 1811 por la Comisión de Materias Eclesiásticas de las mismas. Constaba de un informe sobre su necesidad y una memoria con los aspectos susceptibles de reforma en la Iglesia española, de modo que puede considerarse como el programa del liberalismo en este aspecto ${ }^{2}$. Sin embargo ya en el esbozo de este Concilio se plasmaron las divergencias entre liberales y reaccionarios, puesto que para los primeros debía intervenir en la disciplina de la Iglesia con un

${ }^{1}$ PALACIO ATARD, V. La España del siglo XIX, Espasa, Madrid, 1978, pág. 62.

${ }^{2}$ LA PARRA LÓPEZ, E. Ideas episcopalistas en los planteamientos de política religiosa del primer liberalismo español, en Mayans y la Ilustración: Simposio internacional en el bicentenario de la muerte de Gregorio Mayans, Tomo I, Valencia-Oliva, 1981, pág. 34. 
amplio plan reformista, mientras que para parte de los segundos, las Cortes no tenían legitimidad para intervenir en este asunto y el Concilio debía limitarse a defender el carácter sagrado de la contienda contra el francés.

El proyecto de Concilio Nacional, plasmado en un documento presentado por los liberales junto con los jansenistas, era un alegato a favor del regalismo moderado y del episcopalismo en el sentido de que la autoridad de los obispos no era delegada del Papa, sino que la tenían per se. Daba al poder temporal la posibilidad de intervenir en la disciplina de la Iglesia, pero matizándola en el sentido de que las reformas debían ser llevadas a cabo por los obispos ayudados por los párrocos, mediante concilios y no por el rey, que exclusivamente debía velar por su ejecución. Todo ello quedaba en la línea de los mitificados concilios toledanos. Claramente quedó expresada esta idea al señalar en el informe que « $\mathrm{La}$ Comisión nombrada para preparar las materias de disciplina externa en que debe intervenir la autoridad soberana...». Por otra parte, se aprovechó el documento para lanzar una serie de ataques contra Roma, a la que, además de imputar que extraía gran cantidad de dinero desde España, se achacaba el impedir la celebración de concilios nacionales durante un larguisimo periodo de tiempo, a la par que se indicaba no ser necesaria su autorización para la convocatoria, siendo suficiente que el Primado diese cuenta de sus resultados a la Santa Sede. Se manifestaba que debía estar presidido por este último, con la concurrencia de los obispos y demás personas que determinase. Por último se mencionaba la necesidad de promoción de los párrocos y la ineludible necesidad de disminución del número de clérigos junto con la mejora en su formación y la limitación de las formas barrocas de liturgia. Los obispos de Mallorca y Calahorra, presentes en la sesión de Cortes, se adhirieron a esta convocatoria. Este proyecto conciliar no se llevó a cabo por las dificultades fácilmente comprensibles que existían en un país en guerra, lo que condujo a la intervención directa de las Cortes en esta materia e imprimió un giro en las relaciones Iglesia-Estado imperantes hasta el momento. Sin embargo, periódicamente su convocatoria fue solicitada en diferentes debates, alguno tan tardío como la intervención del obispo de Ibiza a su favor dos días antes del cierre de las sesiones en 1813.

La inauguración de las Cortes se realizó con una Misa del Espíritu Santo y la toma de juramento a los diputados, cuyo primer párrafo, anticipo de lo que iba a ser la legislación en materia de tolerancia religiosa, decía: "¿Jurais la santa Religión católica, apostólica, romana, sin admitir otra alguna en estos reinos?». Inmediatamente las Cortes se atribuyeron, el 24 de septiembre de 1810, la soberanía nacional, lo que en aquellos momentos constituía un acto revolucionario ${ }^{3}$, que puso

3 PÉREZ GARZÓN, J.S. Las Cortes de Cádiz, Editorial Síntesis, Madrid, 2007, pág. 234. 
en sus manos el destino de España. Esta iniciativa partió, entre otros, del canónigo Muñoz Torrero. Tomando como base esta declaración, las Cortes iniciaron la reforma de las relaciones Iglesia-Estado aprovechando a su favor una circunstancia excepcional: el internamiento e incomunicación del Papa en Francia junto con la falta de reconocimiento, por parte de las autoridades españolas, de las atribuciones extraordinarias que decía poseer el Nuncio, lo que originaba un vacío de poder en la Iglesia española. Debe considerarse que estas Cortes hicieron en todo momento una intensa manifestación externa formal de reconocimiento hacia la Iglesia, organizando ceremonias litúrgicas para conmemorar las victorias militares o los aniversarios relevantes y asistiendo a diferentes procesiones.

Ya desde las primeras sesiones se puso de manifiesto que había dos puntos que con carácter de urgencia debían debatirse en las Cortes y que tenían una elevada incidencia en las relaciones Iglesia-Estado: la fiscalidad del nuevo régimen y la libertad de imprenta. A su desarrollo legislativo e incidencia sobre las citadas relaciones dedicamos los siguientes apartados.

\subsection{Medidas fiscales}

Uno de los aspectos que debieron cuidar con más detenimiento las Cortes fue el de proveer económicamente la marcha de la guerra y para ello una de las posibles medidas a adoptar era la utilización de los bienes de la Iglesia.

El tratamiento de los bienes de la Iglesia también debía inscribirse dentro de la política liberal en materia económica presidida por los principios de contribución proporcional y universalidad, junto con la simplificación del procedimiento recaudatorio ${ }^{4}$, así como el reconocimiento y pago de la deuda pública, lo que implicaba considerar a la Iglesia como cualquier otro contribuyente.

En este aspecto económico, cabe diferenciar dos periodos en la actitud de la Iglesia: en el primero que abarcaría hasta 1810, la Iglesia fue una activa colaboradora del régimen liberal; a partir de esa fecha, en este campo al igual que en otros, se empezó a manifestar una creciente resistencia en contra de esta colaboración, que se acrecentó al percatarse el clero que estas reformas económicas a implantar no eran meramente coyunturales para auxilio de la guerra, sino estructurales para definir un nuevo modelo de sociedad.

Argüelles presentó a las Cortes el 27 de noviembre de 1810 un Plan en el que se pretendía racionalizar la aportación de la Iglesia al Estado. También esta

${ }^{4}$ ARTOLA, M. Los orígenes de la España contemporánea, Vols. I y II, Centro de Estudios Políticos y Constitucionales, Madrid, 2000, págs. 498-506. 
vez se encendió la controversia entre liberales y serviles y finalmente los primeros lograron que se aprobase el Decreto de 1 de diciembre de 1810, que impuso la suspensión del nombramiento de determinadas prebendas eclesiásticas con el fin de destinar sus rentas al sostenimiento de los ejércitos, y el de 20 de abril de 1811 para aplicación al erario de ciertas pensiones eclesiásticas. En la línea de equiparación fiscal de la Iglesia con los restantes grupos de la sociedad, la Comisión de Hacienda presentó a las Cortes el 25 de agosto de 1811 una minuta de Decreto, que fue aprobada en la sesión de 27 de agosto, en la que se disponía en su primer artículo que la contribución extraordinaria de guerra, comprendía a todos los españoles, con lo que quedaba clara la sujeción de la Iglesia a la misma y además se indicó que sus representantes entregasen a los Ayuntamientos, encargados de la recaudación de la contribución, una relación de sus rentas para determinar la cuota fiscal que en su día se les podía imponer. Como culminación de este proceso hay que destacar el Decreto de 13 de septiembre de 1813, denominado Nuevo Plan de contribuciones públicas, que eliminaba todas las de los consumos, e imponía un nuevo impuesto general para todos los estamentos, afectando por tanto sin exclusión a la Iglesia, cuya principal riqueza radicaba en sus propiedades inmobiliarias, eliminando las inmunidades existentes. Así según el artículo 19 quedaban sujetas al mismo todas las propiedades al señalar que: «los propietarios o arrendatarios de las fincas rústicas o urbanas pagarán las cuotas que por esta razón se les repartan en los pueblos donde las fincas se hallaren situadas». Debe tenerse en cuenta que el liberalismo, además de ser una ideología política, tenía una fuerte carga económica, por ello Argüelles hizo notar, con posterioridad, la animadversión que estas medidas provocaron en amplios sectores de la Iglesia. Tenemos que destacar que la Comisión de Hacienda que preparó este Decreto mantuvo las rentas de los diezmos de esta última, alegando su carácter igualatorio al indicar que: «...aunque se halla impuesta exclusivamente sobre la agricultura y la ganadería, sin embargo, cualquiera que sea su origen o influencia, conserva cierto carácter de igualdad respectiva entre los contribuyentes, puesto que cada uno de ellos paga en razón directa de lo que cosecha o cría.» Esta idea de los liberales fue modificándose con el tiempo, de modo que se solicitaría la supresión de estos diezmos a cambio de que el Estado se hiciese cargo del mantenimiento del clero con el consiguiente aumento de su influencia sobre la Iglesia.

\subsection{Libertad de imprenta}

Durante los años 1809 y 1810 hubo un intenso movimiento a favor de la libertad de imprenta, que hasta aquellas fechas se encontraba fuertemente limita- 
da. Sin embargo conviene señalar que en todos los liberales que la solicitaban a las autoridades o en todos los llamamientos en prensa y folletos, excepto en el caso del liberal Flórez Estrada, se reconocía que en lo tocante a la religión debía existir una limitación a esta libertad.Todo ello condujo al Decreto referente a la libertad de imprenta publicado el 10 de noviembre de 1810. En la Comisión que redactó el borrador del citado Decreto se encontraban cuatro eclesiásticos y los debates que propició se desarrollaron tanto en relación con las justificaciones políticas como en las consecuencias sobre la Iglesia y la religión. Se ha calificado este Decreto como voluntarioso, pero con una deficiente técnica jurídica, ya que sus artículos no se encuentran agrupados en Capítulos, consecuencia de la rapidez con que fue elaborado 5 .

El articulo 1 señalaba: «Todos los cuerpos y personas particulares, de cualquier condición y estado que sean, tienen libertad de escribir, imprimir y publicar sus ideas politicas sin necesidad de licencia, revisión o aprobación alguna anteriores a la publicación, bajo las restricciones y responsabilidades que se presentarán en el presente Decreto». Además en su texto se incluyó la importante salvedad siguiente en el artículo 6: «todos los escritos sobre materias de religión quedan sujetos a la previa censura de los ordinarios eclesiásticos, según lo establecido en el Concilio de Trento», aunque el artículo 19 permitía la defensa previa de sus ideas al autor. En aquel momento, vigente todavía la Inquisición, pareció un avance incluso a los liberales más exaltados, pues apreciaban que dentro de los obispos existían algunos tolerantes con las reformas, situación que no se daba con el Tribunal citado, que hasta ese momento era el encargado de la censura ${ }^{6}$, y se potenciaba la idea episcopalista, tan cara a este grupo político. Además, como señaló Argüelles: «La Comisión consideró prudente limitar el proyecto de ley a solo opiniones políticas. En esta limitación se hacia un doloroso sacrificio a la libertad de imprenta en obsequio del clero exclusivamente». Por otra parte con el fin de integrar a la Iglesia, se decidió, en el artículo 13, la creación de una Junta Suprema de Censura, que calificaba los escritos con posterioridad a su impresión y atendía los recursos de los autores a los que los obispos hubiesen denegado la licencia de publicación. De esta Junta formaban parte tres eclesiásticos sobre los nueve que la componían.

Los liberales hicieron de este Decreto uno de los puntos capitales de su reforma, pues como señalaba Muñoz Torrero: «la libertad sin la imprenta libre, aunque sea el sueño del hombre honrado, será siempre un sueño», constituyendo, para

5 GARCÍA GARCÍA, R. Constitucionalismo español y legislación sobre el factor religioso durante la primera mitad del siglo XIX (1808-1845), Tirant lo Blanch, Valencia, 2000, pág. 102.

${ }^{6}$ CONDE DE TORENO, Historia del levantamiento, guerra y revolución de España, Centro de Estudios Políticos y Constitucionales, Madrid, 2008, pág. 822. 
ellos, una fuente para el progreso nacional como indicó Argüelles: «porque cuantos conocimientos se ban extendido por Europa han nacido de esta libertad». El ya citado Argüelles señalaría más tarde que la religión era el arma poderosa con la que actuaban los enemigos de las reformas y señalaba que la autoridad religiosa iba a ser árbitro de sujetar a la censura eclesiástica cuantas obras aludieran a las variadas cuestiones que se englobaban bajo la vaga frase de «materias de religión», y en efecto podía ser así dada la implicación en múltiples aspectos de la sociedad que tenía todo lo relacionado con la Iglesia.

Esta libertad de imprenta quedó recogida en el artículo 371 de la Constitución de la siguiente manera: «Todos los españoles tienen libertad de escribir, imprimir y publicar sus ideas políticas sin necesidad de licencia, revisión o aprobación alguna anterior a la publicación, bajo las restricciones y responsabilidades que establezcan las leyes». Es decir se instauró un régimen de enjuiciamiento posterior de los posibles delitos que pudieran acaecer cuando se ejerciese este derecho ${ }^{7}$. En las Cortes de 1820 se interpretó de manera amplia esta libertad de los doceañistas, de modo que se consagraba un principio general de libertad de expresión ${ }^{8}$.

Con el fin de solucionar varios problemas que se presentaron sobre aplicación de este Decreto de 10 de noviembre de 1810, se publicaron otros dos nuevos el 10 de junio de 1813. El primero sobre adiciones a la ley de la libertad de imprenta y el segundo sobre reglamento de las Juntas de Censura. El de adiciones modificó la composición de las Juntas de Censura, ya que en su artículo 2 se señalaba que no podían formar parte de las mismas los Prelados eclesiásticos, los Magistrados y Jueces ni otra persona que ejerciese jurisdicción eclesiástica o civil y además indicó en su artículo 31, que las obras que publicasen los prelados regulares y seculares como particulares deberían seguir los mismos trámites que los restantes ciudadanos. Por último reproducimos su artículo 32, ya que constituye una manifestación y prolongación del regalismo, que los liberales deseaban mantener en las relaciones Iglesia-Estado y suponía una radicalización del mismo: «Si alguna vez ocurriere que las pastorales, instrucciones o edictos que los Arzobispos, Obispos, y demás prelados y jueces eclesiásticos impriman o dirijan a sus diocesanos en el ejercicio de su sagrado ministerio, contengan cosas contrarias a la Constitución o a las leyes, el Rey, y en su caso la Regencia, oyendo al Consejo de Estado en el modo y forma que previene la Constitución respecto a los decretos conciliares y bulas pontificias, suspenderá su curso y mandará recoger los impresos. Si además hallare méritos para formación de causa que in-

7 TORRES DEL MORAL, A. Constitucionalismo histórico español, Universidad Complutense, Madrid, $5^{a}$ ed., 2004, pág. 42.

8 BARRAGÁN BARRAGÁN, J. Temas del liberalismo gaditano, Universidad Nacional Autónoma de México, México, pág. 12. 
duzca desafuero contra el autor o autores, pasará el impreso al Tribunal Supremo de Justicia, siempre que este sea de Arzobispo u Obispo y a la audiencia territorial si fuere de alguno de los demás prelados y jueces eclesiásticos». Por último, el artículo 34 recogía otra de las ideas clave de los liberales en materia de estas relaciones: el incremento de la autoridad de los obispos sobre las órdenes religiosas, al ordenar que los primeros seguirán la causa, en caso de delito de imprenta, contra un eclesiástico regular como si el imputado fuese un eclesiástico secular.

\section{RELACIONES IGLESIA-ESTADO EN LA CONSTITUCIÓN DE 1812}

En el Decreto por el que se declaró la constitución de las Cortes, que llevaba fecha de 24 de septiembre de 1810, se confirmaba la existencia de una Regencia y en la fórmula de juramento que se imponía a la misma se señalaba, a la par que el importantísimo reconocimiento de la soberanía nacional representada en las mismas, la conservación de la religión católica, apostólica y romana.

En el Preámbulo de la Constitución, dentro de la línea confesional de la misma, se ponía a Dios como fuente de la soberanía y el poder, al indicar: «En el nombre de Dios todopoderoso, Padre, Hijo y Espíritu Santo, autor y supremo legislador de la sociedad», eliminando toda referencia al Contrato Social de Rousseau, con lo que se apartaba de las tendencias más extremas de la Ilustración, pero que aún pareció insuficiente a determinados parlamentarios ${ }^{9}$. Esta invocación estaba conforme con la orden de rogativas públicas que hicieron los constituyentes en la sesión de 28 de agosto de 1811, para alcanzar un feliz resultado en la redacción del nuevo texto.

El 2 de septiembre de 1811 se puso a votación el artículo 13 redactado por la Comisión encargada de la redacción en los siguientes términos: «La Nación española profesa la religión católica, apostólica, romana, única verdadera, con exclusión de cualquier otra». Como claramente quedó expresado, se manifestó de modo absoluto la intolerancia religiosa. El debate del artículo llevó a una elaboración más restrictiva del mismo y a la introducción de la posibilidad de continuar el regalismo borbónico, ya que quedó redactado del modo siguiente, como definitivo artículo 12: «La religión de la Nación española es y será perpetuamente la católica, apostólica, romana, única verdadera. La Nación la protege por leyes sabias y justas y probíbe

9 BARRERO ORTEGA, A. Modelos de relación entre el Estado y la Iglesia en la historia constitucional de España, Universidad de Cádiz y Fundación Centro de Estudios Constitucionales 1812, Cádiz, 2005, pág. 14. 
el ejercicio de cualquier otra». La confesionalidad quedaba así establecida no solo para el presente sino también para el futuro; la Nación era y seguiría siendo confesional, de modo que era a quien se atribuía la facultad de optar en materia religiosa. La religión era un derecho objetivo de la Nación, un presupuesto político de la misma y por lo tanto una ley fundamental, a la que un conspicuo liberal, como Muñoz Torrero, indicó que era «el principal deber a que está obligado todo ciudadano» ${ }^{10}$.

Se ha indicado que esta redacción de la Constitución daba lugar a una manifestación de confesionalidad doctrinal, dogmática y excluyente ${ }^{11}$, ya que se proclamaba como única verdadera la religión católica con clara exposición de la intolerancia y expresando además una valoración sobre la misma ${ }^{12}$. La unidad religiosa, tomada como una de las bases de la unidad nacional y de organización de la sociedad, quedó asentada como un factor de extraordinario valor en esta Constitución ${ }^{13}$.

Posteriormente notables liberales como Muñoz Torrero, Argüelles o Toreno intentaron justificar la aclamación con que fue aprobado este artículo, indicando la necesidad de mantener esta intolerancia a ultranza con el fin de tener el máximo consenso para elaborar rápidamente una Constitución que definiese otras libertades y la soberanía nacional y así lo manifestó a posteriori, en 1835, el segundo de los mencionados en su obra «Examen histórico de la reforma constitucional»: «En el punto de la religión se cometía un error grave, funesto, origen de graves males, pero inevitable. Se consagraba de nuevo la intolerancia religiosa, y lo peor era que, por decirlo así, a sabiendas de muchos, que aprobaron con el más profundo dolor el artículo 12. Para establecer la doctrina contraria bubiera sido necesario luchar frente a frente con toda la violencia y furia teológica del clero... Pero se creyó prudente dejar al tiempo que se corrigiese sin lucha ni escándalo el espíritu intolerante que predominaba en una gran parte del estado eclesiástico. Los que se abstuvieron entonces de contradecir los indiscretos términos de aquel artículo, lo bicieron en obsequio de la paz y armonía...» ${ }^{14}$. Muñoz To-

10 BARRero ORTEGA, A. La libertad religiosa en España, Centro de Estudios Políticos y Constitucionales, Madrid, 2006, págs. 31 y 32.

11 LLAMAZARES FERNÁNDEZ, D. Derecho eclesiástico del Estado, derecho de la libertad de conciencia, Servicio publicaciones Facultad de Derecho Universidad Complutense, Madrid, 1989, pág. 159.

12 SUÁREZ PERTIERRA, G. La recuperación del modelo constitucional. La cuestión religiosa a los veinticinco años de la Constitución, Laicidad y libertades, número 2, Madrid, 2002, pág. 315.

13 SUÁREZ PERTIERRA, G. Libertad religiosa y confesionalidad en el ordenamiento jurídico español, Editorial Eset, Vitoria, 1978, págs. 1 y 3.

${ }^{14}$ ARGÜELLES, A. Examen bistórico de la Reforma constitucional que hicieron las Cortes Generales y Extraordinarias en J. Longares, La reforma constitucional de Cádiz, Iter Ediciones, Madrid, 1970 , págs. 262 y 263. 
rrero resumió el sentir liberal al respecto: «En virtud de esta disposición, ningún español puede atacar la religión católica sin quebrantar una ley fundamental del Estado y por consiguiente un delito que puede ser castigado con pena civil. De abi se infiere que debe baber tribunales que protejan y conserven la religión. Pero tanto estos tribunales como las leyes que los regulen deben estar acordes con lo que se previene en la Constitución». La única voz liberal discrepante fue la de José María Blanco White, quién remarcó el sello de intolerancia religiosa que se introducía y añadió esta crítica: «Los españoles han de ser libres en todo, menos en sus conciencias» ${ }^{15}$, y efectivamente preciso es reconocer que se sacrificó la libertad de conciencia a un pacto político que en aquel momento a casi todos contentó.

La interpretación de este artículo, fundamental en las relaciones Iglesia-Estado, provocó unas hondas diferencias entre liberales y reaccionarios y marca el inicio de la denominada «cuestión religiosa», que tan amplia trayectoria habría de tener en el constitucionalismo español, en el ordenamiento legislativo y en los programas de los partidos políticos. La protección a título de regalía dejaba a los liberales las manos libres para intervenir unilateralmente en las reformas de las estructuras externas de la Iglesia para acomodarla al nuevo Estado liberal, de modo que hubiese Tribunales que protegiesen y conservasen la religión, pero acordes con la Constitución ${ }^{16}$, siendo únicamente el poder civil el que disponía de las competencias para proteger la Iglesia católica.

Se ha señalado que esta defensa a ultranza de la religión estaba íntimamente ligada con su concepción como elemento común de los españoles y por lo tanto es lo que soldaba a estos como miembros de una sola Nación. Esta idea se refuerza por la posición que ocupaba el artículo 12 entre el que prescribía la integridad territorial y el que sancionaba la potestad legislativa de las Cortes como símbolo de su soberanía. No ser católico constituía un delito que dañaba al conjunto de la Nación, de modo que lo que surge de la Constitución es una Nación católica, con un modelo distinto al francés y en la que es muy difícil separar la esfera política de la religiosa. ${ }^{17}$ Los liberales de Cádiz abrieron una senda en la que la modernización del Estado no iba acompañada por la secularización del mismo.

Con este artículo no terminaba la modificación que se proponían hacer en la Constitución sobre las relaciones Iglesia-Estado, sino que en la misma se legisló

15 BLANCO WHITE, J. M. Cartas de Juan Sintierra (Crítica de las Cortes de Cádiz), Universidad de Sevilla, Sevilla, 1990, pág. 142.

${ }^{16}$ LA PARRA LÓPEZ, E. El artículo 12 de la Constitución de Cádiz, instrumento contra los liberales en el Trienio, en La Iglesia Española en la Crisis del Antiguo Régimen, UNED, 2003, pág. 139.

17 PORTILLO VALDÉS, J. M. Revolución de nación. Orígenes de la cultura constitucional en España, 1780-1812, Centro de Estudios Políticos y Constitucionales, Madrid, 2000, pág. 137. 
abundantemente sobre éstas, como señalamos seguidamente, dado el carácter minucioso y amplio de este texto, fruto de su propósito de impedir la vuelta al Antiguo Régimen.

En los Capítulos correspondientes a las juntas electorales de parroquia, partidos y provincias se aprecia como la organización electoral se apoyaba en la de la Iglesia, debiendo asistir a las mismas las correspondientes autoridades religiosas, quienes tenían que dirigir un discurso a los asistentes, que debían asistir a una misa solemne al inicio y a un Te Deum al final. La intolerancia religiosa, que fluye por toda la Constitución, se ve remarcada en el artículo 117, en el que se disponía que en el acto de jura de los diputados debían responder, todos los años, a la siguiente pregunta: "¿Juráis defender y conservar la Religión católica, apostólica, romana, sin admitir ninguna otra en el reino?». En cuanto al Rey, se le definía en el artículo 169 como Majestad Católica, tratamiento que no se dio en la de Bayona, y en el 173 se recogía su fórmula de juramento con estas palabras «...juro por Dios y por los santos evangelios, que defenderé y conservaré la religión católica, apostólica, romana, sin permitir otra alguna en el reino...», que era la misma que debían emplear los regentes, y casi con idéntica fórmula se prescribe en el artículo 212 la del Príncipe de Asturias. Al respecto hay que señalar las palabras de Argüelles en Discurso Preliminar de la Constitución donde incluye a la religión como uno de los fundamentos de la Nación: «...porque el respeto, obediencia y fidelidad a la religión, a la ley y al Rey empiezan a ser desde este tiempo los vínculos que le unen más estrechamente a la Nación, que algún día habrá de gobernar».

En el Capítulo I del Título IV, que trataba de los poderes del Rey se encuentra, en su artículo 171, una de las manifestaciones del regalismo, al que tan aficionados eran los liberales de 1812, ya que indicaba que una de sus facultades era la recogida en su punto $6^{\circ}$ : "Presentar para todos los obispados, y para todas las dignidades y beneficios eclesiásticos de real patronato, a propuesta del Consejo de Estado.» Asimismo indicaba en su punto $15^{\circ}$ : «Conceder el pase, o retener los decretos conciliares y bulas pontificias con el consentimiento de las Cortes, si contienen disposiciones generales; oyendo al Consejo de Estado, si versan sobre negocios particulares o gubernativos; y si contienen puntos contenciosos, pasando su conocimiento y decisión al supremo tribunal de Justicia, para que resuelva con arreglo a las leyes». Intimamente ligado con este artículo se encuentra el 237, donde, describiendo las funciones del Consejo de Estado, se señalaba que: «Pertenecerá a este Consejo hacer al Rey la propuesta por ternas para la presentación de todos los beneficios eclesiásticos...». Además este Consejo de Estado, conforme al artículo 232, estaba compuesto por cuarenta miembros, de los cuales serán «... cuatro eclesiásticos, y no más, de conocida y probada ilustración y merecimiento, de los cuales dos serán obispos...». Este organismo también quedó encargado del exequatur para los decretos y bulas pontificias que versasen sobre pun- 
tos particulares o gubernativos, ya que los referentes a asuntos generales quedaron reservados a las Cortes y los de contenciosos al Tribunal Supremo.

El mantenimiento de situaciones provenientes del Antiguo Régimen quedó especificado en el artículo 249, que se englobaba en el Capítulo I del Título V referido a los Tribunales: «Los eclesiásticos continuarán gozando del fuero de su estado, en los términos que prescriben las leyes o que en adelante prescribieren». Argüelles en el Discurso Preliminar, señaló que este artículo era un compromiso del momento histórico ya que señalaba: «La Comisión ha creído que no debia bacerse alteración en el fuero de los clérigos hasta que las dos autoridades civil y eclesiástica arreglasen este punto conforme al verdadero espíritu de la disciplina de la Iglesia española y a lo que exige el bien general del Reino...». Sin embargo el artículo anterior, el 248, proclamó: «En los negocios comunes civiles y criminales, no habrá más que un solo fuero para toda clase de personas». Los debates sobre este artículo 249 fueron amplios ${ }^{18}$ y en ellos quedaron fijadas las opiniones de los liberales doceañistas y de sus oponentes. Entre los primeros destacamos a Calatrava y al Conde de Toreno. Calatrava dijo: «...no se por qué la comisión no ba reducido también a sus justos límites el fuero de los eclesiásticos... El fuero de los eclesiásticos se puede considerar desde bajo dos aspectos, uno sobre los negocios comunes y otro sobre los puramente espirituales y relativos al ejercicio de su ministerio. No bablo del segundo, porque reconozco que la Iglesia debe entender en aquellas cosas que le son particulares. Pero en los asuntos puramente temporales, en las acciones de los clérigos como ciudadanos, no se cómo la comisión ha querido conservar el fuero» y Toreno remachó: «...la administración de justicia debe ser igual para todos, imparcial y ejecutiva». Por último Villanueva recordó que, aunque se aprobase el artículo, este tema debía quedar pendiente de una ulterior concordia entre la Iglesia y el Estado en tiempos más tranquilos, aunque fue aprovechado por el liberal García Herreros para incidir en la teoría regalista tan grata a los liberales: «Todo esto persuade la injusticia con que a V.M. se le disputa la facultad de moderar o derogar el fuero de los eclesiásticos. Sean enborabuena acreedores a las exenciones que disfrutan; pero no incurran en la ingratitud de desconocer la mano que los beneficia para convertir en independencia lo que es pura gracia».

Dentro de este mismo Capítulo, y al referirse al creado como novedad y denominado Supremo Tribunal de Justicia, se encuentra el artículo 261 que recogía sus funciones, entre las que se encontraban las de su punto $8^{\circ}$ : «Conocer de los recursos de fuerza de todos los Tribunales eclesiásticos superiores de la corte». Con ello se iniciaba la posibilidad de unificar, aunque en su escalón más elevado, las dos jurisdicciones existentes.

18 ARTOLA, M. y FLAQUER MONTEQUI, R. La constitución de 1812, Iustel, Madrid, 2008, págs. 413-433.

(C) UNED. Revista de Derecho Político

N. ${ }^{\circ} 82$, septiembre-diciembre 2011, págs. 391-428 
Por lo que respecta al tema de la enseñanza, es muy curioso comprobar cómo se entremezclaban las actividades del Estado y de la Iglesia. En efecto, en el artículo 366 se indicaba que: «En todos los pueblos de la Monarquía se establecerán escuelas de primeras letras, en las que se enseñará a los niños a leer, escribir y contar y el catecismo de la religión católica, que comprenderá también una breve exposición de las obligaciones civiles». No define este artículo quién debía impartir el catecismo, si los sacerdotes o los laicos encargados de la enseñanza y se entremezcla la religión católica con los deberes de los ciudadanos. Pero por otra parte, el artículo 368 recogía que: «El plan general de enseñanza será uniforme en todo el reino, debiendo explicarse la Constitución política de la Monarquía en todas las universidades y establecimientos literarios donde se enseñen las ciencias eclesiásticas y políticas». Este artículo seguía las ideas de Argüelles, expresadas en el Discurso Preliminar, donde señalaba que la educación «ha de ser general y uniforme, ya que generales y uniformes son la religión y las leyes de la Monarquía española». En conjunto, el tema de la enseñanza sufrió una modificación legislativa sustancial, ya que pasó a ser uniforme, pública y con control del Estado frente al que tenía hasta aquel momento la Iglesia.

La presencia de miembros destacados de la Iglesia en puestos relevantes del nuevo régimen instaurado en Cádiz, como ocurrió con la presidencia de la Regencia por el Primado en 1813, fue una materialización de la confesionalidad del mismo y por tanto una expresión de esta característica del sistema político instaurado ${ }^{19}$.

La Constitución deseaba crear una nueva forma de Estado, por ello pretendía acabar con la confusión existente entre éste y la Iglesia, sin llegar a su separación. El liberalismo trató de sustituir la realidad anterior por un Estado confesional, con una religión oficial y una Iglesia sostenida por los fieles a través del Estado. En España la prudencia y la necesidad económica condujo a moderar las declaraciones constitucionales aunque se formuló la idea de la religión oficial y de la protección estatal, que daría lugar, una vez extinguido el diezmo, a la aparición de la contribución de culto y clero.

\section{LOS LIBERALES Y LA SUPRESIÓN DE LA INQUISICIÓN}

Uno de lo temas que suscitó mayores debates en las Cortes fue el de la abolición de la Inquisición, ya que en este Tribunal se formalizaban todas las filias y fobias que respecto a la Iglesia existían en aquel momento histórico. No hay que

19 IBÁN, I. C. El Derecho Eclesiástico de la Zona Nacional durante la Guerra Civil en Anuario de Historia del Derecho Español, Tomo LVII, Madrid, 1987, pág. 641. 
olvidar que al haber suprimido el Gobierno de José I este Tribunal, las opiniones de los liberales favorables a su eliminación quedaron tachadas de afrancesadas por los que deseaban su mantenimiento.

Después de la jornada del 2 de mayo de 1808 todo un conjunto de problemas llevó a la parálisis del Santo Oficio, hasta que la Comisión nombrada al efecto indicó, en julio de 1811, la necesidad de restablecer su funcionamiento, sin que se tomase ninguna decisión práctica al respecto. Los defensores del Tribunal clamaron por su restauración efectiva en la sesión de Cortes de 22 de abril de 1812, aunque no lo consiguieron ${ }^{20}$ debido a dos circunstancias: la primera era un Decreto de las Cortes del día 17 del mismo mes en el que al crear el Tribunal Supremo de Justicia ordenaba la supresión de los denominados Consejos, lo que provocaba o bien la eliminación de la Inquisición o bien su restablecimiento con otro nombre; la segunda circunstancia era el acuerdo de las Cortes de 13 de diciembre de 1811 en el que al terminar la redacción de proyecto de la Constitución se indicaba: "que ninguna proposición que tuviese relación con los asuntos comprendidos en aquella ley fundamental fuese admitido a discusión sin que, examinada previamente por la comisión que habia formado el proyecto, se viese que en modo alguno contraría a ninguno de sus artículos aprobados». Como consecuencia, la Comisión de Constitución encargada, a partir de la aprobación de esta última, de elaborar proyectos de ley para su desarrollo, informó el 4 de junio de 1812 sobre la incompatibilidad existente entre la Carta Magna y este Tribunal; por todo ello se decidió la creación de una nueva Comisión que estudiase el tema a la luz de la Constitución ya aprobada. Sin embargo numerosos obispos pidieron lisa y llanamente el restablecimiento del Tribunal con todas las funciones que había detentado ${ }^{21}$. La confusa situación motivó una pastoral del Cardenal Borbón fechada el 3 de enero de 1813, inspirada por Villanueva, en la que apoyaba la obediencia a un Gobierno que no había atacado a la Iglesia y denunciaba a los predicadores que proclamaban la rebeldía frente al mismo porque no había repuesto la Inquisición.

La Comisión nombrada al efecto y en la que destacaban los clérigos liberales Muñoz Torrero, Oliveros y Espiga, junto con Argüelles, se manifestó en contra de la Inquisición al señalar que: «El santo Oficio es una soberanía dentro de una soberanía, un Estado dentro de otro Estado, una jurisdicción exenta de las leyes del país dependiendo de la Curia de Roma» ${ }^{22}$. El primero de los citados, Muñoz Torrero, de-

${ }^{20}$ CONDE DE TORENO, ob. cit., págs. 1.118-1.119.

${ }^{21}$ MORÁN ORTÍ, M. Revolución y reforma religiosa en las Cortes de Cádiz, Editorial Actas, Madrid, 1994, pág. 85.

${ }^{22}$ FERNÁNDEZ PARDO, F: Juan Antonio Llorente, español maldito, San Sebastián, 2001, pág. 337. 
fendía claramente que la protección de la religión correspondía al poder civil, quién era la única autoridad que debía evaluar la entidad de las infracciones en materia religiosa y la única que determinaba las penas, ya que los que así actuaban eran «infractores de la ley fundamental y, bajo este respecto, reos delante de la autoridad civil» ${ }^{23}$.

Los debates que originó el Decreto, que puso fin a la existencia de este Tribunal, se encontraron entre los más relevantes de las Cortes, de modo que se ha podido decir que constituyeron la primera polémica pública sobre el pasado de España ${ }^{24}$. Además se debatió sobre el papel que la Iglesia debía tener en el nuevo Estado liberal y mereció que fuese editado por las Cortes en un libro singular titulado «Discusión del proyecto de Decreto sobre el Tribunal de la Inquisición».

Los detractores, entre los que señalamos a Muñoz Torrero y Argüelles, manifestaban la incompatibilidad del Tribunal con la Constitución, y con las garantías procesales que ésta contemplaba, así como con el nuevo ordenamiento jurídico centralista, añadiendo que la defensa de la religión quedaba asegurada con lo indicado en el artículo 12 de la misma; además manifestaban que era superfluo y contrario al Evangelio y a la prosperidad del Estado. No debe olvidarse que uno de los principios básicos del liberalismo era la libertad individual, por lo que defendieron esta supresión no con teorías políticas, para evitar ser tachados de afrancesados, sino desde la tradición hispánica de la repulsa que había originado este Tribunal en las Cortes tradicionales, que no habían aprobado su implantación. Otras razones que se esgrimieron en los debates fueron su falta de conexión con el mantenimiento de la fe, así como los problemas de procedimiento y la falta de recurso contra sus decisiones. Además, los defensores del episcopalismo echaban en falta la no intervención de los obispos en este Tribunal, que eran quienes debían salvaguardar la fe de la Iglesia.

El amplio debate que suscitó en las Cortes sirvió para que los doceañistas liberales expusieran sus ideas sobre la Iglesia y el Estado. Así Argüelles manifestó: «Es imposible que haya paz en las naciones, mientras se pretenda que la religión influya en el régimen temporal de los pueblos» y su correligionario, el conde de Toreno: «El objeto de la religión es proporcionar a los hombres su felicidad eterna, lo cual no tiene nada que ver con las leyes civiles». En la misma línea se manifestó Muñoz Torrero al tratar de controlar el poder temporal al eclesiástico: «cuando los principes resisten el abuso de los que ejercen la potestad eclesiástica, no tratan de lo espiritual, sino del ejerci-

23 GARCÍA PÉREZ, J. Diego Muñoz Torrero. Ilustración, religiosidad y liberalismo, Editora Regional de Extremadura, Mérida, 1989, pág. 163.

24 VICENS-VIVES, J. Aproximación a la Historia de España, Ed. Vicens-Vives, Barcelona, 1966, pág. 92. 
cio público», de modo que era un derecho del Estado oponerse a cualquier institución eclesiástica, que resultase contrario al mismo, como era el caso del Santo Oficio $^{25}$.

Con todo ello, la Comisión propuso que se aprobase el siguiente texto de Decreto: $1^{\circ}$ La religión católica, apostólica romana será protegida por leyes conforme a la Constitución. $2^{\circ}$. El tribunal de la Inquisición es incompatible con la Constitución, porque se opone a la soberanía e independencia de la nación y a la libertad civil de los españoles que las Cortes han querido asegurar y consolidar en la ley fundamental». De esta manera se pensaba que sería más fácil que resultase aprobado el Decreto ${ }^{26}$, aunque el debate duró entre el 5 y el 22 de enero de 1813, en que fue finalmente aprobado por mayoría, pero con 60 votos en contra, quedando el punto $2^{\circ}$ reducido a su primera frase. Además este Decreto se complementó con una brevísima introducción en la que se aludía nuevamente al famoso artículo 12 de la Constitución y varios puntos adicionales entre los que destacan el $3^{\circ}$, que establecía los tribunales protectores de la $\mathrm{Fe}$, que juzgarían las ofensas contra ésta «de acuerdo con los cánones y la Constitución», amparándose en las Partidas y restableciendo las facultades en este punto de los obispos, y el $9^{\circ}$ que ordenaba pasar este tipo de causas contra la religión al juez secular una vez terminado el juicio eclesiástico.

Además el Decreto contenía un segundo Capítulo en el que se prohibían los escritos contrarios a la religión y a la disciplina general de la Iglesia, aunque se trató de limitar la arbitrariedad de los obispos en sus exámenes, pero siempre quedaba la duda, como hemos mencionado, de hasta donde se extendía lo que se entendía por religión. Además los juicios de los obispos en esta materia no eran definitivos, ya que sólo el Rey con el consentimiento de las Cortes podía elaborar la lista definitiva de libros prohibidos. Como puede observarse, aunque se suprimió este Tribunal, en ningún modo se estableció la tolerancia religiosa, ni la libertad de conciencia.

El 22 de febrero de 1813 se publicó el Decreto completo, acompañado de un manifiesto de las Cortes en el que se exponían los fundamentos para abolir la Inquisición e instaurar los antedichos tribunales protectores de la $\mathrm{Fe}^{27}$. En este manifiesto, expresión de las ideas liberales doceañistas en materia de relaciones Iglesia-Estado, se reivindicaba a la religión como fundamento del Estado señalando textualmente que «es una ley del Estado» y se resaltaba que la Inquisición no

25 GARCÍA PÉREZ, J. ob.cit., pág. 166.

26 CONDE DE TORENO, ob. cit., pág. 1.204.

27 El texto completo del manifiesto aparece en Discusión del proyecto de Decreto sobre el Tribunal de la Inquisición, Imprenta Nacional, Cádiz, 1813, aquí recogemos lo indicado en sus páginas 689-694.

(C) UNED. Revista de Derecho Político 
era responsable ante nadie, lo que iba en contra de lo dispuesto en la Constitución, ya que la única persona no responsable era el Rey y además se hacia notar que dictaba leyes como un soberano. Se remachaba que los procedimientos que utilizaba eran «obscuros e ilegales» y se proclamaba las ideas episcopalistas al citar que «los obispos por derecho divino son los jueces de las causas eclesiásticas» y como consecuencia de esta promulgación «es protegida la autoridad episcopal y los jueces seculares ejercen su poder sosteniendo el juicio de los Obispos. Orden conforme a la religión y a la ley constitucional, que lejos de contradecirse, guardan entre si la más perfecta armonía». Con el fin de tranquilizar a todos se indicaba que «no piensen ni imaginen en modo alguno que pueden quedar impunes los delitos de berejía».

Junto con este Decreto, se publicaron con la misma fecha otros tres complementarios: el que ordenaba leer el primero de los indicados junto con el manifiesto, durante tres domingos consecutivos en todas las parroquias; el que mandaba quitar y destruir las pinturas o inscripciones de castigos impuestos por la Inquisición y, finalmente, el que declaraba nacionales los bienes del Tribunal y fijaba el sueldo y destino de sus componentes.

La lectura provocó una división en la Iglesia, y el enfrentamiento de una parte de ésta con los liberales, ya que algunos miembros de la misma se negaron y otros la aceptaron a regañadientes, señalando la necesidad de instaurar rápidamente los tribunales de Fe creados por el mismo Decreto. En el centro de estos manejos contrarios a su difusión se encontraba el Nuncio Gravina y parte de la Regencia ${ }^{28}$, e incluso el primero de los mencionados insistió en la nulidad de la nueva norma porque iba en contra de la primacía del Papa e intrigó para que se pidiese permiso, para su lectura, previamente a los diferentes cabildos. Los distintos manejos dieron lugar a la no lectura en Cádiz el día 7 de marzo, tal como estaba previsto, y originaron la reacción de los diputados liberales y el cambio de Regencia, que pasó a estar presidida por el Cardenal Borbón. Con estos cambios se procedió a la lectura del Decreto de abolición de la Inquisición en los templos, aunque en algunos casos, como el del arzobispo de Santiago, prefirieron ausentarse antes que dar su autorización. Se ha señalado que la postura de los obispos fue de gran rechazo en su mayoría, de aceptación reservada en algunos y de adhesión en muy pocos, tan solo en dos de una manera inequívoca ${ }^{29}$, de modo que el Decreto se aprobó en unas Cortes con gran participación eclesiástica, aunque con evidente rechazo y escasa aceptación por parte de la Iglesia.

${ }^{28}$ CONDE DE TORENO, ob. cit., pág. 1.220.

29 HIGUERUELA DEL PINO, L. Actitud del episcopado español ante los decretos de supresión de la Inquisición: 1813 y 1820, en La Inquisición española. Nueva visión, nuevos horizontes, I simposium internacional sobre la Inquisición celebrado en Cuenca, Madrid, 1980, págs. 939-977. 
Como hemos mencionado, con la misma fecha de 22 de febrero de 1813 se declararon nacionales todos los bienes de la Inquisición, quedando así desamortizados, y a continuación el siguiente 13 de septiembre fueron regulados para pago de la deuda, procediéndose a la abolición de los derechos que percibía en las aduanas el 22 marzo de 1813.

Pero no terminaron aquí los problemas que suscitó este Decreto, sino que el 23 de abril de 1813, la Regencia remitió una nota al Nuncio en la que desaprobaba su conducta proclive a la no lectura del mismo y en razón de que era representante del Papa no procedía a su expulsión. En la respuesta del Nuncio de fecha 28 de abril replicó no reconociendo ningún error en sus actuaciones, ya que indicaba se limitaban a aspectos puramente espirituales. Además el Cardenal Borbón como Regente y Primado envió una nota a los obispos y cabildos en la que pedía su colaboración para desarrollar las intenciones de las Cortes y la Regencia a favor del mejor entendimiento de las relaciones Iglesia-Estado y añadía una serie de consideraciones de extrema gravedad sobre la conducta del Nuncio: «Ha faltado este ilustre personaje a las leyes de su legación, al respeto debido al Congreso Nacional y a la confianza que le abriga en su seno un Reino católico» ${ }^{30}$. Ante esta situación, y otros problemas que más adelante se indican, el 7 de julio tomó la Regencia la decisión de expulsión del Nuncio, quien el 14 de ese mes se retiró a Portugal, originándose una grave crisis en las relaciones Iglesia-Estado. Además el Nuncio continuó manteniendo correspondencia con diferentes obispos, tramitando dispensas y tratando de formar con diferentes prelados un bloque antiliberal. No se quedó a la zaga la Regencia en este punto y publicó un manifiesto el 8 de julio de 1813 en el que haciendo una cerrada defensa de las regalías, señalaba públicamente que la falta de respeto a las mismas por el Nuncio era lo que había provocado su exilio.

\section{ACTUACIONES DE LOS LIBERALES EN LA REFORMA DE LAS ÓRDENES RELIGIOSAS Y DESAMORTIZACIÓN}

La actitud de los regulares contraria, en su mayoría, a los afrancesados había provocado su disolución por José I. A medida que la suerte de las armas se fue volviendo favorable en 1812, a partir de la batalla de los Arapiles, al Gobierno de Cádiz, y se iban ocupando poblaciones, algunos profesos trataban de recuperar sus conventos incautados por el gobierno napoleónico, a lo que se sumó una am-

30 RODRÍGUEZ LÓPEZ-BREA, C. M. Don Luis de Borbón, el cardenal de los liberales (17771823), Junta de Comunidades de Castilla-La Mancha, Toledo, 2002, pág. 232. 
plia campaña de prensa, tanto a favor como en contra de la devolución de conventos. Además, como para los liberales y jansenistas era preciso realizar reformas en las órdenes religiosas, se creó el caldo de cultivo necesario para que las Cortes estudiasen este problema de acuerdo con el mandato de restablecimiento y reforma de conventos que recibieron. Ya en el número 20 de la Gaceta de 1812, los liberales hacían referencia a la disminución de estima popular hacia el clero regular y se indicaba que eran ruinosos para la Nación, señalándose que debían ocuparse de la enseñanza, la cura de almas y la asistencia en los hospitales, porque «considerados políticamente, la existencia de los conventos y monasterios es incompatible con el estado actual de las cosas» ${ }^{31}$. La prensa liberal apoyaba esta actitud, como ocurrió con El Conciso en su número de 22 de septiembre de 1812, al señalar: «Las autoridades civiles o los soberanos pueden, por el bien de sus estados, no solo reformar las órdenes religiosas, sino deshacerse de ellas, sin esperar a un concilio que lo haga ni a un Breve pontificio». Al igual que ocurrió en el tema de las dispensas, que más adelante expondremos, también aquí chocaron el Nuncio y el Primado Cardenal Borbón, como Visitador, sobre quién tenía la autoridad para la reforma, pero las diferentes instituciones del Estado, Cortes, Regencia y Consejo de Estado, dejaron bien claro que el primero no tenía competencia en estos asuntos ${ }^{32}$, de modo que el Cardenal reinició la labor encomendada por la Bula «Inter Graviores» en la época de Carlos IV, con la aquiescencia de las sucesivas Regencias, aunque con muchas dificultades y recelos. A esto hay que añadir que el Consejo de Castilla, como órgano del Estado, siguió entendiendo de los recursos de fuerza interpuestos por los regulares, hasta su abolición en 1812.

En la línea marcada por la prensa liberal en contra de los regulares, el 17 de junio de 1812 se publicaba un Decreto por el que se reintegraba a las órdenes religiosas lo que había confiscado el gobierno afrancesado siempre que se dictaminase el restablecimiento del citado convento, de modo que mientras esto no ocurriese el Gobierno se apropiaba de las rentas. En su artículo 7 decía: «tendrá lugar el secuestro y la aplicación de frutos a beneficio del Estado cuando los bienes, de cualquier clase que sean, pertenezcan a establecimientos públicos, cuerpos seculares, eclesiásticos o religiosos de ambos sexos, disueltos extinguidos o reformados por resultas de la invasión enemiga o por providencias del gobierno intruso; entendiéndose lo dicho con calidad de reintegrarlos en la posesión de las fincas y capitales que se les ocupen, siempre que llegue el caso de su restablecimiento, y con calidad de señalar sobre el producto de sus rentas los alimentos precisos a aquellos individuos de dichas corporaciones que, debiendo ser mantenidos por

31 Gaceta de Madrid bajo el Gobierno de la Regencia no 20, Septiembre 1812, págs. 204-208.

32 RODRÍGUEZ LÓPEZ-BREA, C. M. Frailes y revolución liberal, Editorial Azacanes, Toledo, 1996, págs. 89-93. 
las mismas, se bubiesen refugiado a las provincias libres, profesen en ellas su instituto, y carezcan de otros medios de subsistencia». La amplitud con la que quedó redactado hubiera dado pie a la disminución de conventos, como indicaron diversos liberales, entre los que señalamos a Toreno ${ }^{33}$, y en este sentido la Secretaría de Hacienda remitió una Instrucción a los intendentes el 21 de agosto del mismo año. Detrás de este Decreto se encontraba la necesidad de disponer de bienes susceptibles de ser vendidos y de ese modo aliviar la carga que suponía la deuda pública que pesaba sobre el Estado, a la par que se satisfacía a la naciente burguesía, principal detentadora de los títulos de dicha deuda.

En la sesión de 18 de septiembre de 1812, se presentó un dictamen de la Comisión de Hacienda en el que se insistía en la necesidad de aplicar el Decreto de 17 de junio, pero fue derrotada, lo que implicaba la obligación de devolver los conventos a sus antiguos poseedores. Esta derrota fue debida a que gran parte de los denominados jansenistas unieron sus votos a los reaccionarios contra los liberales, lo que da idea de la falta de uniformidad ideológica que se daba en ocasiones en las Cortes de Cádiz. El Ministro de Hacienda y la Regencia eran decididos partidarios de ir restituyendo los conventos a las órdenes a medida que se iban recuperando poblaciones, aludiendo a que no se podía desatender a los fieles y que además los frailes no debían quedar sin cobijo, y en este sentido se tomaron medidas en diferentes localidades, lo que daba lugar a altercados y agravios comparativos. Esta actuación de la Regencia ayudó a su cese, aunque éste principalmente se debió, como ha quedado expuesto, a su actuación en la supresión de la Inquisición. Por el contrario, el Ministro de Gracia y Justicia, Cano Manuel, autodenominado "encargado de la alta policía eclesiástica» y de acuerdo con el canónigo Villanueva, presentaron ante las Cortes un Plan de reducción de conventos. En este plan quedaban recogidas ideas clave de los regalistas y de los liberales, ya que en relación con los primeros se señalaba que el Estado podía legislar en materias de disciplina externa de la Iglesia, sin necesidad de contar con ésta y por lo que respecta a las ideas liberales, se señalaba que el Estado liberal no podía acoger estamentos privilegiados, lo que obligaba a que los regulares se sujetasen a las instrucciones del Gobierno, todo ello en conexión con la idea que relacionaba las necesidades de la Hacienda con las propiedades de los conventos.

Con el fin de unificar criterios, el órgano legislativo decidió la creación de una Comisión mixta (Hacienda, Eclesiástica y Confiscos y Secuestros) que, tras largas deliberaciones, emitió el 21 de enero de 1813 el «Dictamen de las comisiones encargadas de informar a las Cortes sobre el restablecimiento y reforma de

33 CONDE DE TORENO, ob. cit., pág. 1.211.

(C) UNED. Revista de Derecho Político 
las casas religiosas». Este documento constaba de seis puntos fundamentales y un anexo. Los puntos son tres referidos al restablecimiento de conventos y otros tres a la reforma de los regulares; en el anexo aparecía el documento pontificio expedido en 1802 por Pío VII a favor del Cardenal Borbón para que llevase a efecto esta reforma. Los autores expusieron la necesidad de realizar primero el restablecimiento y luego la reforma, con el fin de evitar el relajamiento que se estaba observando en aquellos frailes que no volvían a sus conventos ${ }^{34}$. Los comentarios que acompañaban a cada punto permiten hacer un resumen de las ideas que inspiraron a los liberales y jansenistas doceañistas en este aspecto de las relaciones Iglesia-Estado: restablecimiento de la disciplina antigua, episcopalismo y continuidad de las ideas ilustradas. Sin embargo hay que indicar que el Dictamen nunca llegó a ser aprobado en las Cortes.

En los puntos referentes al restablecimiento de los conventos, indicaban que, debido a su influencia en el orden social, debían obtener el permiso de la Regencia que solo lo concedería si se cumplían las condiciones que a continuación se exponen, pero debe resaltarse que en ningún momento se hacía referencia a permisos de las autoridades de la Iglesia: Los religiosos que quisieran reinstaurar su comunidad, debían presentarse al Jefe político o Alcalde constitucional, quien debería informar favorablemente. Deberían ser como mínimo 12 y se hacia mucho hincapié en que tenían que disponer de los medios para su subsistencia, debiendo quedar reducidas a una las casas en aquellos lugares que hubiera varias de la misma orden. Se les autorizaba para que administrasen los bienes de los conventos, sin posibilidad de que éstos se incrementasen, pero debía intervenir una persona designada por el Ayuntamiento, quien remitiría las cuentas al Intendente provincial junto con las observaciones necesarias, es decir se instauraba una intervención civil en las cuentas eclesiásticas. No se permitía restablecer los conventos que hubiesen quedado totalmente destruidos y se prohibía la existencia de conventos de monjas en despoblado. De estas condiciones cabe deducirse una amplia aplicación de los principios regalistas con un notorio intervencionismo estatal.

En cuanto a la reforma de los conventos, se hacía referencia a la relajación a la que habían llegado, se reconocía la autoridad real para llevarla a cabo y se proponía, como hemos mencionado, la aplicación de la Bula papal, de modo que el proliberal Cardenal Borbón, Regente del reino, debía completar la labor que años atrás no fue capaz de terminar, pero ahora tenía la ayuda de la autoridad soberana de la cual él, en ese momento, formaba también parte y contaba con la colaboración de los visitadores que designase, aunque éstos debían tener la aprobación del

${ }^{34}$ Dictamen de las comisiones encargadas de informar a las Cortes sobre el establecimiento y reforma de las casas religiosas, Imprenta Nacional, Cádiz, 1813, pág. 3. 
Gobierno, con lo que quedaban a salvo los principios regalistas. Por otra parte, el exilio del Nuncio, visitador ordinario de los regulares, favorecía esta reforma. En este apartado se indicaba la reducción del número de conventos de monjas, que no debía pasar de 350 y además el número de profesas en cada uno de ellos debía oscilar entre 21 y 30 . Por otra parte, no se admitían novicios de menos de veintitrés años y no se permitía profesar antes de los veinticuatro, se limitaba la adquisición de propiedades por parte de las órdenes religiosas, se prohibía a los conventos que recibiesen la herencia de los profesos y se eliminaban las dotes. Conviene mencionar que la limitación del número de profesos no se amparaba solo en cuestiones espirituales, sino que se hacía una interesante referencia a las de orden económico y fiscal para las que se citaba a los ilustrados. Por último, como claro precedente de lo que habría de ocurrir años después en los procesos desamortizadores, se indicaba la «necesidad de evitar que se estanquen los bienes raices.»

Sin embargo la falta de interés de los diputados liberales en el tema de la reforma, que contrastaba con la de sus aliados jansenistas, hicieron que el tema no progresase, quedando únicamente en el ideario liberal la necesidad de utilizar los bienes de los regulares para alivio de la deuda pública.

Con el fin de unificar criterios en materia de restauración de conventos, elaboraron las Cortes un nuevo Decreto el 18 de febrero de 1813 en el que se permitía la reconstrucción de las comunidades autorizadas hasta el momento por la Regencia en determinadas zonas de España, con la salvedad de que no estuviesen arruinados los edificios y prohibiendo, a la par, la solicitud de limosnas para su reconstrucción. Además, se repetía que debían tener un mínimo de 12 profesos y solo se autorizaba una casa de cada orden en cada población.

Como la financiación de la contienda seguía siendo un tema de capital importancia, el Gobierno a través de una exposición de sus ministros de Hacienda, Guerra y Gobernación, propuso a las Cortes el 4 de julio de 1813 una desamortización en la que se incluían, entre otros, una serie de bienes tanto del clero secular como del regular. Entre estos figuraban los conventos que estaban siendo administrados, en aquel momento, por Hacienda. Aunque esta propuesta no prosperó, sirvió de base para futuras actuaciones desamortizadoras al igual que el Decreto de 13 de septiembre del mismo año, en el que se ha querido ver el germen de una amplia política de trasformación social de cuño netamente liberal ${ }^{35}$, siendo incluso clasificado de revolucionario ${ }^{36}$ por la utilización de conventos

35 RODRÍGUEZ LÓPEZ-BREA, C. M. Don Luis de Borbón..., pág. 239.

36 BARRIO GOZALO, M. Reforma y supresión de los regulares en España al final del Antiguo Régimen (1759-1836), Revista de Investigaciones Históricas, época moderna y contemporánea, no 20, Universidad de Valladolid, Valladolid, 2000, pág. 106. 
suprimidos, declarados bienes nacionales junto con otros bienes comunales y eclesiásticos, para la extinción de la deuda pública.

En algunos lugares reconquistados al Gobierno josefino, se vivieron momentos de tensión, ya que los regulares ocuparon los conventos, pero los intendentes les obligaron a desalojar algunos de ellos. Un nuevo Decreto de 26 de agosto de 1813 indicó que mientras las Cortes decidían sobre el Plan presentado, la Regencia entregase algunos conventos en los que se cumplían las condiciones de Decretos anteriores a las que añadió dos: que estuviesen en poblado y que el edificio reuniese las necesarias condiciones de habitabilidad, lo que dio lugar a interpretaciones dispares y en general puede decirse que existió bastante confusión en la restitución de conventos.

Hay que mencionar que la entrega no presuponía el traspaso de la propiedad y era un acto de gracia que quedaba a expensas de la aprobación del restablecimiento definitivo y la reforma. Como prueba de esta confusión, hay que señalar que el 10 de septiembre de 1813 se presentó en las Cortes una proposición para devolver todos los conventos, comprometiéndose éstos a ingresar a la Hacienda pública una parte de sus rentas ${ }^{37}$. El citado Decreto de 13 de septiembre del mismo año aplicó al Crédito público los bienes de los conventos administrados por el Gobierno y supuso la apertura de una vía desamortizadora, que habría de tener en el futuro importancia decisiva en la Historia de España y que para los liberales doceañistas era de suma relevancia pues respaldaba el reconocimiento de los títulos de deuda pública, cuya mayoría eran detentados por la nueva burguesía que apoyaba al régimen. Las ideas de los doceañistas liberales en este punto habían quedado meridianamente expuestas por Antonio Cano Manuel, Secretario de Gracia y Justicia, en la sesión de 14 de mayo de 1813, cuando se expresó sobre el derecho de la Iglesia sobre sus bienes: «Es un privilegio, una gracia, y ésta es la mayor prueba de que no hay propiedad, porque en tanto necesitaban de privilegio en cuanto carecian de título de propietario».

En definitiva, se trató de diseñar una notable reforma, fruto de la combinación de criterios de utilidad, que provenían de los ilustrados, y de los deseos de aumento de la estricta observancia religiosa, acompañados de una notable injerencia estatal, pero las Cortes no realizaron ninguna exclaustración masiva ${ }^{38}$. Dentro de su ideología, los liberales pretendieron limitar las jurisdicciones exentas por lo que el choque con los institutos religiosos, dependientes de Roma, era inevitable. No hay que olvidar que todos estos deseos se mezclaban

37 RODRÍGUEZ LÓPEZ-BREA, C. M. Frailes y revolución..., págs. 143-155.

38 REVUELTA GONZÁLEZ, M. La Iglesia Española en el siglo XIX. Desafíos y respuestas, Universidad Pontificia de Comillas, Madrid, 2005, pág. 120. 
con los principios económicos del liberalismo, en orden a movilizar la riqueza detentada por las manos muertas y que fueron el origen, como hemos señalado, de futuras modificaciones importantísimas en la esfera de las propiedades de la Iglesia. Sin embargo la descoordinación entre la Regencia, las Cortes, los intendentes y otros funcionarios, dieron lugar a una notable confusión en las actuaciones y a la postre a un fracaso en este campo de la primera experiencia liberal, inmersa en una guerra que absorbía gran parte de sus energías.

\section{LOS LIBERALES Y EL PROBLEMA DE LAS DISPENSAS. EL NOMBRAMIENTO DE OBISPOS}

Los liberales defensores del episcopalismo se constituyeron como un grupo ideológico cuyas ideas tuvieron una gran resonancia jurídica en los debates de las Cortes e influyeron en el nuevo enfoque que se quería dar a las relaciones IglesiaEstado. Este grupo tenía como idea motriz que los obispos debían gozar de plenas facultades para el gobierno de sus diócesis, de modo que el Papa quedaba como centro de unidad, sin ser un orden jerárquico. Esta idea se complementaba con la de que el Estado podía intervenir en los asuntos de la Iglesia. En este punto, las Cortes no tuvieron una voluntad de ruptura con el Papa, ya que se limitaron a tratar de terminar o limitar las reservas que la Curia pontificia había acumulado, reivindicando los derechos de los obispos ${ }^{39}$.

El papel que debía seguir o no ejerciendo Roma aparece en los proyectos sobre nuevas relaciones Iglesia-Estado que discutieron los liberales, de modo que pueden considerarse una continuación de las ideas ilustradas y del regalismo que las acompañaba. Con todo ello se pretendía una supremacía del poder político frente al de la Iglesia, de modo que una de las formas de plasmar esta idea era mediante la promoción del citado episcopalismo y una de sus manifestaciones principales era la devolución a los obispos de la capacidad para dispensar impedimentos matrimoniales.

En este punto de las dispensas era de capital importancia la actitud del Nuncio que había salido con la corte desde Madrid hacia Aranjuez en 1808, durante la huída de aquella, y de allí pasó al Puerto de Santa María. Debido a esta precipitada huída, no pudo disponer de los documentos que, según decía, le acreditaban para controlar las dispensas matrimoniales. Sin embargo el cardenal

39 REVUELTA GONZÁLEZ, M. La Iglesia española ante la crisis del antiguo régimen (18081833), en Historia de la Iglesia en España (dir. García Villoslada, R.), Tomo V, La Iglesia en la España Contemporánea, Biblioteca de Autores Cristianos, Madrid, 1979, pág. 37. 
Borbón en enero de 1809 se dirigió a los obispos con el fin de coordinar las actuaciones en esta materia debido a la incomunicación con la Corte papal, a la vez que el Secretario de la Junta Central, Martín de Garay, hacía lo mismo con el Nuncio, quien proclamó que, aun no disponiendo de las acreditaciones necesarias, éstas existían y se encontraban en Madrid. El cardenal Borbón tomó la iniciativa, ya que señalaba al Nuncio: «Cuando la Santa Sede se halla imposibilitada de proveer por si, mi derecho es indispensable a socorrer almas que me fueron encargadas en el mismo instante de mi ordenación con todos los auxilios y consuelos espirituales de que pueden tener necesidad... No necesito mendigar autoridad. Jesucristo me la dio... V.E. se abstenga de conceder gracias y dispensas, porque me sería extraordinariamente sensible y doloroso verme en la necesidad de suspender su curso y contribuir contra mi voluntad al desaire que indispensablemente había de sufrir la respetable firma de V.E. ${ }^{40}$. Aun así, el Primado era partidario de la concesión obispal de dispensas solo en determinados casos. Todos estos diferentes puntos de vista originaron una división del episcopado español, ya que para unos era plenamente lícito en las circunstancias existentes que los obispos reasumiesen sus facultades, mientras que para otros debía ser el Nuncio en exclusiva quien las detentase.

El 6 de Mayo de 1810, Eusebio de Bardaxi y Azara, a la sazón Secretario interino de Estado, informó al Nuncio que la Regencia había determinado que los ordinarios, en sus respectivos distritos, «están en el caso de usar de las facultades que les competen, mientras subsista el Santo Padre en el estado de opresión en que se halla en poder del enemigo común, disponiendo en los impedimentos de matrimonio..., y que se haga saber a V.E. para que lo tenga entendido y se sirva de no hacer uso de otras facultades que las comprendidas en su nombramiento». Como puede apreciarse se hace referencia exclusivamente a la detención del Papa, pero no se alude a los derechos originarios de los obispos. El Nuncio contestó acatando esta decisión.

Una Real Orden de la Regencia de 12 de mayo de 1810, inspirada asimismo por Bardaxi, facultaba al episcopado para que «ejerza, en este caso extraordinario, y mientras dure la falta de comunicación con la Silla Apostólica, y sin perjuicio de ella, las facultades que le están declaradas, dispensando en los impedimentos de los matrimonios y en los demás casos que ocurran...». Es decir, después de dos años de discusiones, el Estado decidía a quién competía el otorgamiento de las dispensas matrimoniales.

Sin embargo, el Nuncio no cejó en su empeño. Cuando se incorporó a la Regencia el obispo de Orense, apeló a él, lo que motivó que ésta atendiese a su pe-

40 SIERRA NAVA, L. La reacción del episcopado español ante los decretos de matrimonios del ministro Urquijo de 1799 a 1813. Publicaciones de la Facultad de Filosofía y Letras de la Universidad de Deusto, Bilbao, 1964, págs. 171 y 172. 
tición para que comunicase en privado las dispensas que se le solicitasen ${ }^{41}$. Como puede observarse, estas medidas no hacían sino aumentar la confusión y mantener la división, casi por la mitad ${ }^{42}$, dentro del episcopado español. Simultáneamente el Consejo de España e Indias preparó un dictamen en el que solicitaba al Nuncio la presentación de las credenciales con sus facultades extraordinarias. Este indicó que la mayor parte de los prelados le pedían la ratificación de las dispensas concedidas, pero el Consejo dictaminó en 1813 que se confirmase la resolución de la Regencia del 12 de mayo de 1810 al indicar que: «... no puede negarse que el Obispado contiene toda la plenitud de facultades necesarias para gobernar la Iglesia y, en consecuencia, de estas facultades usaron de ellas para dispensar los cánones,... El Consejo desearía la celebración de un Concilio Nacional...». Además se añadía: «...El Consejo persuadido como está de que el M.R. Nuncio no se balla autorizado para el uso de facultades extraordinarias...» y se remarcaban las facultades regalistas, recordando que una concesión de tal categoría a un representante del Papa aumentaría los derechos del Tribunal de la Nunciatura y disminuiría las disposiciones tomadas por los reyes sobre una jurisdicción extraña ${ }^{43}$. A causa de este problema con las dispensas y de la división que hemos comentado entre partidarios del Nuncio y del Primado de Toledo, junto con los enconos que suscitó, contribuyeron, a la par que otras divergencias que hemos expuesto, a la expulsión del primero ${ }^{44}$.

Debido a que, como hemos señalado, los liberales querían incrementar las atribuciones de los obispos era para ellos necesaria la renovación de este colectivo. Para ello no dudaron en declararse parte interesada en el nombramiento de los mismos, con el fin de controlar esta situación. Así se comprende que desde el inicio de las Cortes se estudiase una modificación del sistema para proveer las diócesis, como ocurrió en la sesión de 21 de noviembre de 1811, y se ocupase del mismo el Consejo de Castilla desde el mes de marzo de 1810. En estas condiciones, con varias sedes vacantes, sin que se previese la finalización de la contienda y mientras durase la incomunicación con la Santa Sede, era preciso que la Nación, según un informe del Consejo de Estado de 31 de mayo de 1813, tomase cartas en el asunto, ya que se señalaba su obligación de hacerlo, y aquí entraba el regalismo más profundo, por la protección que debía a la Iglesia. Con todo ello se manifestaba la necesidad de que la confirmación de obispos se hiciese por los arzobispos correspondientes con el consentimiento del resto de los provinciales, y

${ }^{41}$ SIERRA NAVA, L. ob. cit., pág. 175.

42 RODRÍGUEZ LÓPEZ-BREA, C. M. Don Luis de Borbón..., pág. 179.

43 SIERRA NAVA, L. ob. cit., págs. 177 y 178.

44 REVUELTA GONZÁLEZ, M. La Iglesia española ante la crisis ..., pág. 60. 
la de los primeros por el más antiguo de la provincia igualmente con el consentimiento de los restantes de la misma, según las antiguas leyes canónicas, debiendo las Cortes emitir el Decreto correspondiente. Sin embargo, una parte muy importante del propio Consejo, entre la que se encontraba el Cardenal Borbón, emitió un voto particular en el que manifestaban que no había necesidad de proveer las diócesis vacantes, dado que los cabildos podían suplir a los obispos en estas circunstancias ${ }^{45}$. Como resultado de lo anterior, el 20 de junio de 1813, basado en el informe del Consejo de Estado, las Comisiones Eclesiástica y de Justicia elaboraron el «Dictamen del Consejo de Estado y de las Comisiones Eclesiástica y de Justicia reunidas sobre el modo de suplir las confirmaciones de los obispos electos» en el que propusieron un borrador de Decreto donde se indicaba que el Papa había usurpado para si el nombramiento de obispos y, por la incomunicación existente, era preciso volver a la antigua disciplina sin el trámite de Roma. El sistema de designación, que seguía al pie de la letra lo indicado por el informe arriba indicado, se inspiraba en la Constitución Civil del Clero francés, aunque hubo diputados discrepantes que se opusieron basándose en la división que existía en este punto en el propio Consejo de Estado y en la necesidad de que fuese la propia Iglesia española quien resolviese «en materia tan difícil como delicada».

Por otra parte, el dictamen aprovechaba la circunstancia de su elaboración para añadir un punto que resultaba fiel reflejo de las ideas liberales en materia de relaciones Iglesia-Estado, al decir que «para hacer precaver los males de la incomunicación es necesario hacer cesar las reservas, no en este punto solo, sino en todos aquellos que se extienden, y declarar que los obispos habian entrado en el uso de su plena autoridad que éstas habian restringid $0^{46} \%$. Por lo tanto no se trataba sólo de proponer el procedimiento para nombrar nuevos obispos, sino de conferirles también la plena auto$\operatorname{ridad}^{47}$, que se completaba con la supresión de las denominadas jurisdicciones exentas que disminuían la de los primeros. Nos encontramos por tanto con una de las máximas expresiones del episcopalismo y del regalismo, tan caros ambos a los liberales y jansenistas, aunque manifestando la situación excepcional que se vivía en aquel momento, tanto por la guerra como por la incomunicación de Pío VII. Este dictamen fue mandado imprimir, aunque no se fijó fecha para su dis-

45 LA PARRA LÓPEZ, E. El primer liberalismo y la Iglesia. Las Cortes de Cádiz, Instituto de estudios Juan Gil-Albert, Alicante, págs. 99 y 100.

46 Dictámenes del Consejo de Estado y de las Comisiones Eclesiástica y de Justicia reunidas sobre el modo se suplir las confirmaciones de los obispos electos durante la actual incomunicación con la Silla Apostólica, con la minuta de Decreto que las mismas Comisiones presentan a la deliberación de las Cortes Generales y Extraordinarias, Cádiz, Imprenta Nacional, 1813, pág. 31.

47 LA PARRA LÓPEZ, E. Ideas episcopalistas..., pág. 38. 
cusión. Dentro de este grupo liberal, Oliveros en la sesión de 26 de agosto de 1813 propuso además una nueva división territorial de los obispados, que debía estar acorde con la de las provincias, de modo que la Regencia debía imponer unos plazos dentro de los cuales los propios obispos debían hacer propuestas en este sentido, que serían aprobadas por la Regencia tras oír el Consejo de Estado.

Las liberales doceañistas realizaron la provisión de cargos eclesiásticos, como manifestó el Secretario de Gracia y Justicia en la memoria que presentó ante las Cortes el 3 de marzo de 1814, en línea con el Decreto de 1 de diciembre de 1810 en el que quedaba prohibida esta provisión a los obispos, y que había originado un fuerte choque con el arzobispo de Santiago. Además en este punto hay que citar el artículo 237 de la Constitución, ya mencionado, y el artículo 4 del Capítulo II del Reglamento del Consejo de Estado, que señalaba: «será por fin de cargo del Consejo, con arreglo a la Constitución, formar y presentar al Rey o a la Regencia las ternas para la presentación de los beneficios eclesiásticos...».

Conviene dejar constancia de que una de las ideas que con más insistencia sostuvieron los liberales doceañistas a lo largo del periodo de sesiones de las Cortes fue también la defensa, al igual que de los obispos, del clero parroquial.

\section{LOS LIBERALES Y OTROS ASPECTOS DE LAS RELACIONES IGLESIA-ESTADO}

Dentro del periodo en el que permanecieron activas las Cortes de Cádiz, además de su intervención en los asuntos relativos a las relaciones Iglesia-Estado que hemos expuesto, aparecieron otros que indicamos seguidamente.

El artículo $1^{\circ}$ del proyecto de Ley contra los infractores de la Constitución, que se presentó el 13 de julio de 1813 , disponía que se tratasen de igual manera a los laicos y a los eclesiásticos; el artículo $2^{\circ}$ volvía a incidir en la intolerancia religiosa al señalar: «el que conspire directamente y de hecho a establecer otra religión en las Españas, o a que la Nación española deje de profesar la religión católica será perseguido como traidor y sufrirá pena de muerte», señalando también que se consideraba infractor de una ley fundamental, y por tanto incurso en un delito político ${ }^{48}$. Esta ley quedó aprobada el 18 de abril de 1821 y en definitiva sanciona al trasgresor no por su error en materia religiosa sino por ser contrario al Estado ${ }^{49}$. También aquí chocaron liberales y reaccionarios, puesto que estos últimos pretendieron re-

48 ÁLVAREZ ALONSO, C. Un rey, una ley, una religión (Goticismo y Constitución histórica en el debate constitucional gaditano), Historia Constitucional (revista electrónica), nº 1, CEPC, 2000, pág. 47.

49 BARRERO ORTEGA, B. La libertad..., pág. 35. 
forzar la redacción en un sentido aun más restrictivo, pero no conviene olvidar en este punto las ideas que tenían ilustres liberales como Muñoz Torrero, quién no dudó en manifestar ante las Cortes, en su sesión de 22 de abril de 1812: «ningún español puede atacar la Religión Católica, hablando ni escribiendo contra ella, directa o indirectamente, sin quebrantar una ley fundamental del Estado y, por consiguiente sin cometer, a más de un pecado sujeto a las penas eclesiásticas, un delito que merece ser castigado con pena civil». Este proyecto estaba en línea con el Decreto de 13 de abril de 1813 sobre concesión y fórmulas de las cartas de Naturaleza y de Ciudadano, ya que en el mismo se establecía de forma incontestable que para las primeras era absolutamente imprescindible que el solicitante hiciese constar que era católico, apostólico y romano, siendo éste por tanto un requisito previo a la concesión de la nacionalidad española. Todo ello guardaba coherencia con lo estipulado en la Constitución, ya que la Nación había hecho suya la confesión de fe de sus ciudadanos y la había recogido como una de sus propiedades determinantes ${ }^{50}$.

El 14 de octubre de 1812, las Cortes declararon abolido el Voto de Santiago, que, al igual que ocurrió al Gobierno de José I, era una constante desde los ilustrados. Se denunció la falsificación de sus orígenes, a la par que se declaró extinguido el 29 de agosto el fuero privilegiado que lo acompañaba, por estar en contra del artículo 248 de la Constitución. Los debates que se suscitaron fueron también amplios y dieron motivo al lucimiento de los oradores liberales, como el Conde de Toreno ${ }^{51}$, que encontraron un asunto en el que podían deslindar los campos civil y eclesiástico, de modo que disminuían la influencia y poder de la Iglesia en nombre del Estado que representaba a los ciudadanos ${ }^{52}$. Sin embargo tres meses antes, las mismas Cortes habían dispuesto el nombramiento de Santa Teresa de Jesús como patrona de España, en un Decreto de 28 de junio. Este nombramiento tiene para algunos autores el símbolo de ser una propuesta realizada en aras de una iglesia nacional, en oposición y sin consulta con Roma ${ }^{53}$.

En la línea liberal de anulación del sistema fiscal de la Iglesia sobre los feligreses, no profundizaron las Cortes en la supresión de los diezmos ya que iba en contra de otra idea, ya mencionada: la potenciación del clero parroquial, principal beneficiario de esta gabela. Parte del clero liberal era contrario a la abolición de estos diezmos, ya que consideraban al clero como un funcionario, fuera de las ataduras con Roma, que debía alimentarse de la colectividad, de modo que ésta

50 PÉREZ GARZÓN, J. S. ob. cit., pág. 363.

51 VARELA SUANZES-CARPEGNA, J. El Conde de Toreno. Biografía de un liberal, Marcial Pons, Madrid, 2005, pág. 67.

52 REVUELTA GONZÁLEZ, M. La Iglesia española ante la crisis ..., pág. 45.

53 MORÁN ORTÍ, M., ob. cit., pág. 57. 
aportaba la ayuda para el sostenimiento de parroquias y párrocos. En este sentido se pronunciaron diputados liberales en sesiones de las Cortes ${ }^{54}$.

\section{INFLUENCIA DE LAS IDEAS LIBERALES EN LAS RELACIONES IGLESIA-ESTADO}

La influencia de lo legislado en Cádiz fue muy relevante a lo largo de todo el siglo XIX, tanto en España como en América, contribuyendo a una mitificación de la labor allí realizada ${ }^{55}$. Los liberales señalaron al clero como el enemigo encarnizado de las obras realizadas en la Constitución de 1812, proclamaron las limitaciones que habían introducido en el texto para contentar a la Iglesia y se lamentaron del poco rendimiento que tal acción les había producido. La influencia jurídica y política de estos planteamientos fue muy relevante durante todo el siglo XIX y principios del XX.

Se ha defendido la idea de bloques compactos que se opusieron o defendieron sin fisuras lo legislado en Cádiz. Es un tema que, como hemos expuesto, debe ser examinado cuidadosamente pues dentro del clero, en materia de relaciones Iglesia-Estado, se presentaron opiniones dispares y dentro de los liberales los hubo de muy diferente criterio, como se manifestaría en el Trienio Liberal ${ }^{56}$, debiendo tenerse en cuenta que tuvieron que adaptarse a las ideas del grupo jansenista, que actuó como aliado suyo, lo que motivó un exacerbado regalismo ${ }^{57}$. Asuntos como la reforma de la Rota, la anulación de la reserva romana de las dispensas, la reforma de las órdenes religiosas o la exaltación de la autoridad episcopal, que para el grupo jansenista de las Cortes constituían en si mismos objetivos importantes, tenían más bien un aspecto instrumental para los liberales doceañistas. Estos obligados a realizar la implantación de las reformas a través del marco confesional, proclamado en la Constitución de 1812, tenían que aspirar a un mayor control sobre una institución nacional tan relevante como era la Iglesia, con la correspondiente disminución de la autoridad de la Santa Sede ${ }^{58}$. Calatrava manifestaba las ideas de muchos liberales al proclamar en la sesión de las Cortes ce-

54 ARTOLA, M. Los orígenes..., págs. 507 y 508.

55 PÉREZ GARZÓN, J. S. ob. cit., pág. 248.

56 RODRÍGUEZ LÓPEZ-BREA, C. M. ¿Fue anticonstitucional el clero español? Un tópico a debate, Pasado Y Memoria, nº 1, 2002, págs. 6-8.

57 CUENCA TORIBIO, J. M. El componente religioso de la Guerra de la Independencia, en El comienzo de la Guerra de la Independencia, Congreso Internacional del Bicentenario, Editorial Actas, Madrid, 2008, pág. 59.

58 MORÁN ORTÍ, M. ob. cit., pág. 118. 
lebrada el 26 de enero de 1813: «Soy y quiero ser católico, apostólico y romano, pero quiero ser libre, deseo cumplir mis deberes, pero no quiero ser el juguete de un déspota ni la victima de un fanatismo». Estos primeros liberales eran claramente católicos y fieles seguidores de la idea de unidad de creencias, pero tratando de disminuir el protagonismo de la Iglesia, aunque utilizándola, si era preciso, en los momentos de tensión que aparecieron a lo largo de la Guerra ${ }^{59}$, de modo que la plasmación jurídica de sus decisiones no fue muy profunda.

La interpretación del fondo ideológico de todas las medidas jurídicas en materia de relaciones Iglesia-Estado emanadas de las Cortes entre 1810 y 1813, no es una tarea sencilla, aunque la tendencia general fue hacia la modificación de la primera sometiéndola al segundo. Se observa que aun entre los mismos liberales había fuertes discrepancias, que originaron líneas contrapuestas de política debido a la confluencia en muchos temas, para su aprobación en las Cortes, de los liberales puros con los jansenistas. Así, por ejemplo, los primeros tuvieron que oír en silencio que uno de sus principales aliados jansenistas, Villanueva, proclamase que «la Iglesia estaba en el Estado y el Estado en la Iglesia» y estos últimos vieron cómo los liberales dejaban sin aprobar la reforma de las órdenes religiosas. En perspectiva comparada, su obra legislativa fue menos agresiva que la de los afrancesados $^{60}$, aunque recibieron influencias de ellos, o por lo menos éstos sirvieron como espejo de emulación. Finalmente se consiguió una reforma, excesiva para los serviles y pacata para los exaltados. La evolución en el tiempo de los debates en las Cortes en el periodo 1810-1813 y de sus correspondientes Decretos muestra que paulatinamente se fueron imponiendo las ideas del grupo más reformador.

Por lo tanto, en general, puede decirse que las reformas en las relaciones Iglesia-Estado fueron tímidas, ya que mucho quedó en planes y soflamas oratorias; comparada con la profunda y relevante reforma política, la de las relaciones citadas resultó mucho más limitada en la plasmación efectiva de los Decretos. Sin embargo hay que resaltar el significado teórico que adquiría el nuevo planteamiento de los asuntos de la Iglesia y del factor religioso, hasta entonces en gran medida intocables y vedados a toda revisión y crítica ${ }^{61}$, que suscitaron una reacción apasionada en gran parte de la Iglesia española. La acción revolucionaria y

59 ÁlVAREZ JUNCO, J. Mater Dolorosa: la idea de España en el siglo XIX, Taurus, Madrid, 2005, pág. 349 .

${ }^{60}$ RODRÍGUEZ LÓPEZ-BREA, C. M. La destrucción de la Iglesia del Antiguo Régimen en Italia y España. Una visión comparada, en La Iglesia Española en la crisis del Antiguo Régimen, UNED, Madrid, 2003, pág. 167.

${ }^{61}$ REVUELTA GONZÁLEZ, M. La Iglesia española ante la crisis..., pág. 58. 
anticlerical trastocaba el sistema del Antiguo Régimen que tenía en la Iglesia uno de sus más relevantes fundamentos, de modo que disminuía considerablemente el papel de ésta dentro del Estado.

La influencia de las ideas defendidas por los liberales en Cádiz se expresaron en tres direcciones en años sucesivos: actuaciones reformistas producto de la revolución liberal, avance del ambiente secularizado y reducción de la influencia de la Iglesia sobre el Estado. Para ello se mantendrán como acciones concretas del programa político liberal la supresión de la Inquisición, la modificación del sistema fiscal, la disminución o supresión de conventos y su incidencia económica con las desamortizaciones correspondientes, así como el deseo de lograr una Iglesia más dependiente del Estado y menos de Roma. Estas acciones, iniciadas suavemente en Cádiz, se aplicarán de modo más decidido en el Trienio Liberal y se consolidarán algunas de ellas en la minoría de Isabel II. Como consecuencia de este desarrollo doctrinal, la adscripción política después de 1823 determinó la conducta religiosa de cada cual, creando el anticlericalismo de gran relevancia en la historia contemporánea de España y con notoria influencia en su desarrollo ${ }^{62}$. Sin embargo, no debe dejar de tenerse en cuenta que, durante esta primera etapa liberal, el Papa se encontraba en un régimen de severa incomunicación en Francia por estar cautivo de Napoleón lo que originó unas especiales circunstancias en las relaciones Iglesia-Estado, que no volverían a repetirse en el futuro, donde la influencia y actividad de la Curia romana serán decisivas., pero a partir de la Constitución de Cádiz, la Iglesia tuvo que tener en cuenta las construcciones constitucionalistas para desarrollar dentro de las mismas su vida pública.

Title:

THE LIBERALS OF 1812 AND CHURCH-STATE RELATIONS

\section{Summary:}

1. INTRODUCTION; 2. PROJECT FOR A COUNCIL. FISCAL MEASURES AND FREEDOM TO PRINT: 2.1 Fiscal Measures; 2.2 Freedom to Print; 3. CHURCH-STATE RELATIONS IN THE CONSTITUTION OF 1812; 4. THE LIBERALS AND THE SUPPRESSION OF THE INQUISITION; 5. LIBERAL POLICY REGARDING REFORM OF RELIGIOUS ORDERS AND SEIZURE AND SALE OF CHURCH PROPERTY (desamortización); 6. LIBERALISM AND

${ }^{62}$ DUFOUR, G. La Iglesia y el control de las conciencias en España al final del Antiguo Régimen, en La Iglesia Española en la Crisis del Antiguo Régimen, UNED, 2003, pág. 91. 
THE PROBLEM OF DISPENSATIONS. THE APPOINTMENT OF BISHOPS; 7. LIBERAL VIEWS ON OTHER ISSUES RELATING TO CHURCH-STATE RELATIONS; 8. INFLUENCE OF LIBERAL IDEAS ON CHURCH-STATE RELATIONS

\title{
Resumen:
}

Los liberales que gobernaron parte de España en el periodo 1808-1813 pusieron en marcha una serie de importantes reformas que afectaron a las relaciones Iglesia-Estado, ya que deseaban modificar todas las estructuras políticas y sociales provenientes del Antiguo Régimen. Para ello trataron de alterar la organización de la Iglesia, sin variar los dogmas de la misma, pero acomodándola a las ideas liberales. Las medidas fiscales que legislaron, así como la libertad de imprenta tuvieron una amplia difusión; sin embargo, aunque la Constitución de 1812 modificó varios aspectos de las relaciones Iglesia-Estado, mantuvo una férrea intolerancia religiosa. Por el contrario, la supresión de la Inquisición dio un aire nuevo a la vida de los españoles y el episcopalismo, defendido junto con los jansenistas a la par que otras medidas, supuso una tentativa de ampliación de la autoridad de los obispos frente a Roma, lo que se tradujo en una reforma del otorgamiento de dispensas y en el nombramiento de estas jerarquías. Los liberales, siguiendo esquemas regalistas e ilustrados, intervinieron asimismo en la reforma y reducción de conventos y quisieron sentar las bases de futuras desamortizaciones. Su influencia a lo largo de los siglos XIX y XX fue muy importante y motivó que la Iglesia hubiese de considerar las construcciones constitucionalistas en su actuación pública.

\begin{abstract}
:
The liberals that ruled over part of Spain between 1808 and 1813 started a series of important reforms that influenced Church-State relations, as liberalism intended to change all political and social structures originated under the Ancien Régime. Liberalism attempted to alter Church organization so as to adapt it to liberal ideas, without changing Church dogmas. The fiscal measures adopted through legislation, along with the freedom to print, had wide application. However, although the 1812 Constitution modified various aspects of Church-State relations, it maintained a staunch religious intolerance. Conversely, the suppression of the Inquisition was a breath of fresh air into Spanish life. Among other measures, Episcopalism, defended side by side with the Jansenists, was an attempt at enhancing the authority of bishops as opposed to that
\end{abstract}


of Rome. It resulted in a reform of the system governing the granting of dispensations and the appointment of bishops. The liberals, following regalist and enlightened ideas, also intervened in the reform and reduction of the number of convents and tried to set the stage for future seizure and sale of church property (desamortizaciones). Liberal influence during the $19^{\text {th }}$ and $20^{\text {th }}$ centuries was wide and deep, forcing the Church, when acting in the public square, to take into account constitutionalist thought.

Palabras clave:

Relaciones Iglesia-Estado, liberalismo, Constitución de 1812.

Key words:

Church-State relations, liberalism, 1812 Constitution. 
